\title{
Lauro Bretones, um protestante heterodoxo no Brasil de 1948 a 1956
}

\author{
Orientador: Paulo Fernando Carneiro de Andrade \\ Doutorando: Fabio Py Murta de Almeida \\ Área de Concentração: Teologia Sistemático-Pastoral \\ Linha de Pesquisa: Religião e Modernidade
}

O presente trabalho tem objetivo de mostrar o personagem religioso heterodoxo, Lauro Bretones, autor, esquecido pelos batistas brasileiros e pelas pesquisas sobre o protestantismo no Brasil. Ou seja, a vontade primeira da tese é de apresentar o jovem teólogo batista e sua produção inconformada a modernidade, depois, objetiva-se percebê-lo como signatário de uma tendência "cristã romântica" na qual migra da Europa para o Brasil de leitores românticos e de cristãos identificados com o romantismo. Levando-o a construir uma visão de mundo distinta a época estilhaçando, por ela, uma produção numinosa diferenciada, impregnada de críticas a Civilização Moderna Ocidental com as seguintes características: anticapitalismo, antiliberalismo, anti-individualismo, antitotalitarismo, antitecnologia, antiguerras e antiestruturas religiosas. Além de propor na sua juventude uma saída à civilização moderna a partir da ideia de profetismo, no qual, entende como chave de articulação em prol da transformação da modernidade capitalista brasileira.

Palavras-chave: Lauro Bretones. Cristianismo romântico. Heterodoxia protestante. 